Article

\title{
Reconstructing Turbidity in a Glacially Influenced Lake Using the Landsat TM and ETM+ Surface Reflectance Climate Data Record Archive, Lake Clark, Alaska
}

\section{Carson A. Baughman ${ }^{1, *}$, Benjamin M. Jones ${ }^{1, \dagger}$, Krista K. Bartz ${ }^{2}$, Daniel B. Young ${ }^{3}$ and Christian E. Zimmerman ${ }^{1, \dagger}$}

1 Alaska Science Center, U.S. Geological Survey, 4210 University Drive, Anchorage, AK 99508, USA; E-Mails: bjones@usgs.gov (B.M.J.); czimmerman@usgs.gov (C.E.Z.)

2 Southwest Alaska Network, National Park Service, 240 W. 5th Ave., Anchorage, AK 99501, USA; E-Mail: krista_bartz@nps.gov

3 Lake Clark National Park and Preserve, National Park Service, One Park Place, Port Alsworth, AK 99653, USA; E-Mail: dan_young@nps.gov

$\dagger$ These authors contributed equally to this work.

* Author to whom correspondence should be addressed; E-Mail: cbaughman@usgs.gov;

Tel.: +1-907-786-7059; Fax: +1-907-786-7150.

Academic Editors: Daniel J. Hayes, Santonu Goswami, Guido Grosse, Xiaofeng Li and Prasad S. Thenkabail

Received: 29 June 2015 / Accepted: 14 October 2015 / Published: 20 October 2015

\begin{abstract}
Lake Clark is an important nursery lake for sockeye salmon (Oncorhynchus $n e r k a$ ) in the headwaters of Bristol Bay, Alaska, the most productive wild salmon fishery in the world. Reductions in water clarity within Alaska lake systems as a result of increased glacial runoff have been shown to reduce salmon production via reduced abundance of zooplankton and macroinvertebrates. In this study, we reconstruct long-term, lake-wide water clarity for Lake Clark using the Landsat TM and ETM+ surface reflectance products (1985-2014) and in situ water clarity data collected between 2009 and 2013. Analysis of a Landsat scene acquired in 2009, coincident with in situ measurements in the lake, and uncertainty analysis with four scenes acquired within two weeks of field data collection showed that Band 3 surface reflectance was the best indicator of turbidity $\left(r^{2}=0.55\right.$, $R M S E<0.01$ ). We then processed 151 (98 partial- and 53 whole-lake) Landsat scenes using this relation and detected no significant long-term trend in mean turbidity for Lake Clark
\end{abstract}


between 1991 and 2014. We did, however, detect interannual variation that exhibited a non-significant $\left(r^{2}=0.20\right)$ but positive correlation $(r=0.20)$ with regional mean summer air temperature and found the month of May exhibited a significant positive trend $\left(r^{2}=0.68\right.$, $p=0.02$ ) in turbidity between 2000 and 2014. This study demonstrates the utility of hindcasting turbidity in a glacially influenced lake using the Landsat surface reflectance products. It may also help land and resource managers reconstruct turbidity records for lakes that lack in situ monitoring, and may be useful in predicting future water clarity conditions based on projected climate scenarios.

Keywords: Climate Data Records; essential climate variables; Landsat TM; Landsat ETM+; Lake Clark; turbidity; sockeye salmon; water clarity; freshwater ecosystems

\section{Introduction}

Water clarity is an important aspect of freshwater lake systems [1,2]. Increases or decreases in water clarity can negatively impact biological components of the system that may be adapted to specific light-penetrating conditions [3-5]. While some systems are adapted to poor water clarity conditions [6], many lakes and rivers are characterized by clear water and are negatively impacted by reductions in light penetration [7]. Reductions in water clarity can inhibit solar energy absorption into lake systems, thereby slowing radiant heating of lakes and reducing photosynthetic production [8]. These changes can lead to cascading effects within food webs including reduced primary productivity, reduced macrophyte and zooplankton availability, and reduced food energy available to higher trophic levels including macroinvertebrates, mollusks, and fish [9]. In Alaska, reductions in water clarity within lake systems have been shown to reduce sockeye salmon and Arctic grayling (Thymallus arcticus) production via reduced abundance of zooplankton and macroinvertebrates [5].

Water clarity is often estimated visually using a Secchi disk or measured directly with nephelometry [10]. Secchi disk transparency (SDT) is measured by lowering a standardized disk in a lake and recording the depth of disappearance, the Secchi depth [11]. This depth is typically measured in meters. Nephelometers provide a direct measurement of the amount of light scatter in a sample of water. Measurements are then compared to standards with known water clarity and are commonly reported as Nephelometric Turbidity Units (NTU) [2]. While these two measures of water clarity are different, they are often highly correlated [2] and are a common component to any monitoring program focused on assessing conditions and trends in water clarity over time [12].

Another approach to monitor water clarity uses remote sensing techniques. The use of air- and space-borne sensors can be practical when the water quality characteristics of interest can be related to its spectral reflectance properties [12] and field survey data are available for ground truthing and upscaling. A remote sensing approach yields comprehensive and cost effective estimates of water clarity compared to on-the-ground point measurements [13]. Temporal and spatial patterns of water clarity may be more accurately captured when using whole-lake imagery rather than point measurements [14]. Furthermore, water clarity measurements can be reconstructed using the decadal-scale database of 
historical and available satellite imagery [13]. Such space-based assessments of water clarity have been used in a variety of aquatic ecosystems around the world over the last 30 years $[13,15-18]$.

Since the early 1970s, the Landsat satellite program has captured images of the global land masses and represents the longest continuous image archive currently available. The Thematic Mapper (TM) sensor onboard Landsat 4 (16 July 1982-14 December 1993) and Landsat 5 (1 March 1984-5 June 2013), the Enhanced Thematic Mapper (ETM+) sensor onboard Landsat 7 (15 April 1999-present), and the Operational Land Imager (OLI) sensor aboard Landsat 8 (11 February 2013-present) offer a near continuous chronology of scenes at a spatial resolution of $30 \mathrm{~m}$ for the entire planet with a 16 day revisit interval. Both Landsat 5 and 7 were operational between 1999 and 2013, which effectively shortened the return interval to eight days [12]. In high latitudes the side-lap between scenes (when two adjacent scenes cover the same swath of ground) becomes more common than at low latitudes where sidelap is intentionally minimal. This further shortened effective return interval makes high latitude regions around the globe potentially more data rich when it comes to scene availability. However, cloud cover can interfere with land surface reflectance especially in Alaska [19]. Both the TM and ETM+ sensors acquire earth reflected light at approximately $0.45-0.52 \mu \mathrm{m}$ (Band 1), 0.52-0.60 $\mu \mathrm{m}$ (Band 2), 0.63-0.69 $\mu \mathrm{m}$

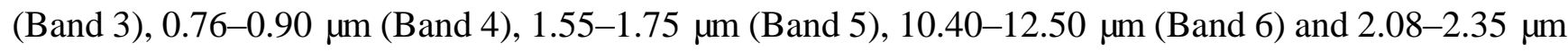
(Band 7) wavelengths. Bands 1-4 are regularly utilized for water clarity assessment, including measuring suspended sediments within glacially influenced lakes in Alaska [20]. In 2013, the U.S. Geological Survey began reprocessing Landsat archives to produce calibrated land surface reflectance products that serve as a Climate Data Record (CDR) and support Earth surface change studies (http://landsat.usgs.gov/CDR_LSR.php). The archive is derived from Level-1T products and completely intercalibrated across sensors. CDR surface reflectance data are inherently orthorectified since they are derived from the Level-1T (radiometrically calibrated, precision and terrain corrected) product.

In this study, we investigated the spatial and temporal fluctuations of a seasonal sediment plume in Lake Clark, Alaska, using summertime (May to October) Landsat TM and ETM+ surface reflectance data acquired between 1985 and 2014. We compiled an image stack consisting of 151 images and developed a relation between field measurements of water clarity acquired between 2009 and 2013 to remotely estimate and reconstruct water clarity within the glacially influenced lake. This allowed us to analyze the spatial and temporal patterns of lake-wide turbidity over a $\sim 30$-year period and propose probable mechanisms driving the remotely sensed patterns of observed change. Reconstructing turbidity of the lake will aid in evaluating how fish habitat varies over time and the potential response of water clarity in glacially influenced lakes to climate change.

\section{Study Area}

Lake Clark is a large $\left(311 \mathrm{~km}^{2}\right)$, elongated $(65 \mathrm{~km} \times 6 \mathrm{~km})$, glacially influenced lake located in southwest Alaska's Lake Clark National Park and Preserve (Figure 1). The NE to SW oriented lake is oligotrophic, polymictic, and resides in a glacially steepened depression within the Lake Clark Fault [21-23]. Bathymetry of the lake consists of two distinct basins and maximum depth is $265 \mathrm{~m}$. For the purpose of this study, we divided the upper basin into two portions; the upper and middle basin. Six tributaries contribute the majority of runoff into the lake. One is organically stained, two are clear, and three tributaries are glacier fed [22]. Suspended sediment contributions come primarily from the 
Tlikakila River and lesser amounts from Currant Creek and the Chokotonk River [24]. Seasonal runoff from glacial tributaries represents approximately $30 \%-50 \%$ of Lake Clark's annual water budget and is highest between June and September [22]. Glacial melt makes up about $10 \%$ of the runoff within these tributaries and Mid-July has been identified as the period of peak sediment input [22,24]. The primary glaciers contributing this sediment are the unnamed glaciers located in the North Fork and Glacier Fork of the Tlikakila River, and the Tanaina Glacier [25]. This input creates a turbidity gradient along the length of the lake $[22,23]$ and a dynamic suspended sediment plume can regularly be seen during the summer and fall (Figure 1), with the highest levels occurring near the mouth of Tlikakila River [24]. By August, this gradient extends throughout the lake with the lowest levels $(<2.0 \mathrm{NTU})$ near the SW outlet of the lake [22,23]. It is this suspended sediment that most significantly limits light penetration within the water and therefore primary productivity [23].

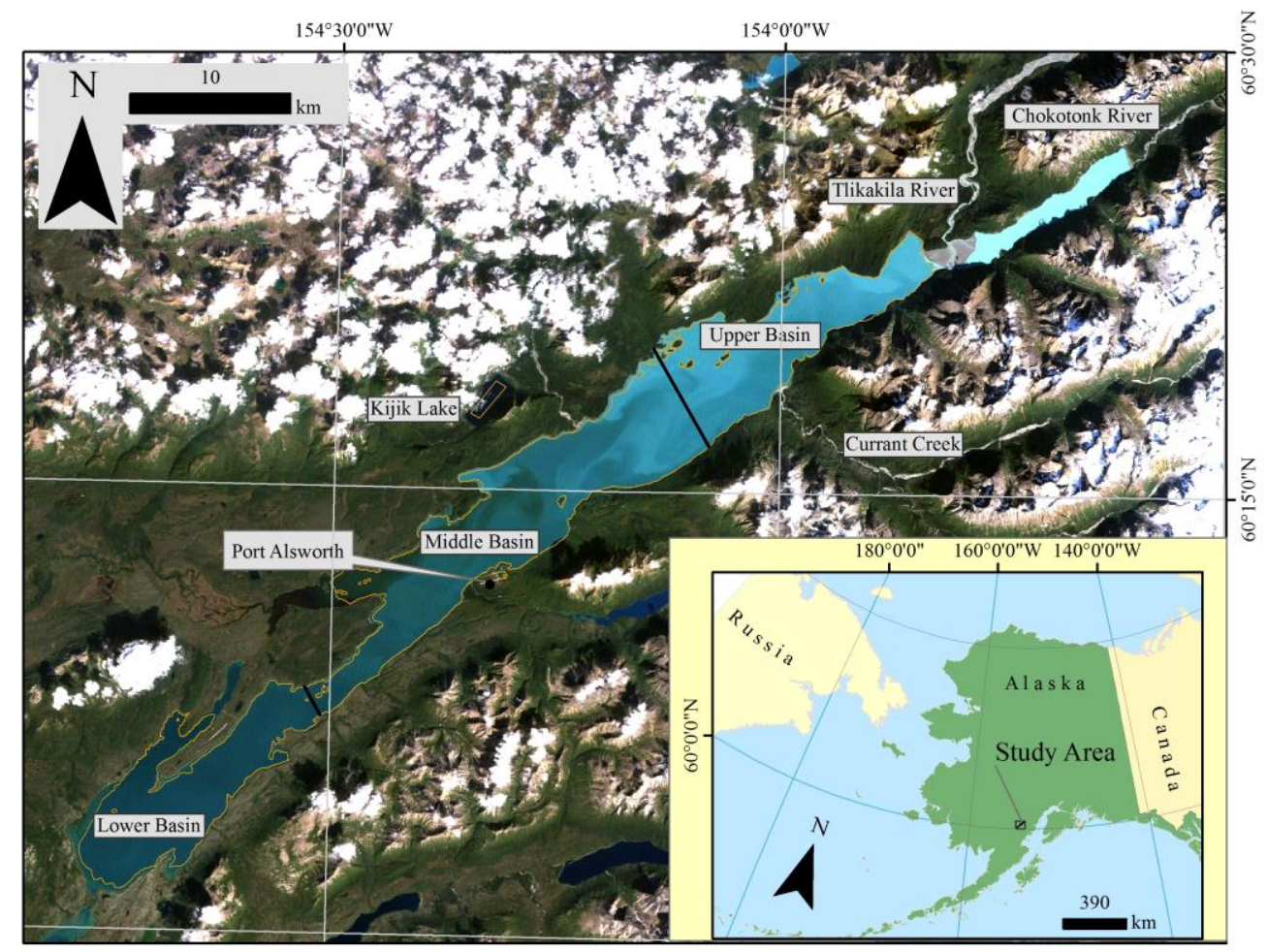

Figure 1. Regional setting of Lake Clark. The background is a Landsat 5 scene taken 3 September 1995 that shows the turbidity gradient within Lake Clark. Black lines denote division of Lake Clark into upper, middle and lower basins.

\section{Methods}

\subsection{Overview}

A common series of steps is required to estimate water clarity remotely. Field measurements of water clarity are compared with a simultaneously acquired Landsat image. Relations between band signatures and field measurements are examined and the strongest relation is used for estimating water clarity in additional scenes. These estimates should be compared against additional simultaneously acquired field 
measurements to validate the model. Following model validation, available imagery can be converted into water clarity estimates. Additionally, our study required standardizing historical water clarity field measurements into Nephelometric Turbidity Units and a novel approach for model validation due to an absence of additional instances where field measurements and Landsat scenes were collected simultaneously. The abundance of cloud cover in many images necessitated additional image processing. Lastly, we analyzed estimated water clarity for trends and relation to environmental factors.

\subsection{Standardization of Existing Water Clarity Measurements}

Field measurements of water clarity via SDT were acquired by the National Park Service between 2009 and 2012 at random locations selected by using generalized random tessellation stratified analysis [26,27]. Concurrent measurements of water clarity via SDT and nephelometry using a Hach 2100Q portable turbidimeter (NTUM) were acquired 12-26 August $2013(\mathrm{n}=30)$ and 15-17 July 2014 $(n=30)$. In order to standardize the different measures of water clarity, we developed a non-linear function between the concurrent measures of SDT and turbidity data (NTUM) using the samples collected in August 2013 and July 2014. The resulting function was used to convert any in situ SDT measurements into correlative Nephelometric Turbidity Units (NTUC).

\subsection{Model Selection and Testing}

NTUC values collected between August 19th and 25th, 2009 were compared to a TM scene acquired on August 24, 2009 from Landsat 5. This is the only date where field measurements were taken at the same time a scene was acquired by Landsat. We used simple linear regression to develop a relation between in situ measurements and the space-based observations. NTUC values were compared to the corresponding cell value of four $(n=4)$ independent bands (Bands $1-4)$ and eight $(n=8)$ different band combinations consisting of Bands 1-4, including the Normalized Difference Turbidity Index (NDTI) which is calculated as (B3 - B2) / (B3 + B2) (Table 1). These bands and combinations are regularly employed to detect suspended sediments in water bodies [12,17,28-30]. We selected the best fit relation based on R2 and RMSE values following multiple linear regression. This regression equation was then used to predict known measurements of NTUC and NTUM data collected between 2009 and 2013 using Landsat TM or ETM+ images. Since a temporal offset of 12-38 days characterized all subsequent instances of turbidity measurements and Landsat overflights, traditional model validation was not possible. We assume that, for a working model, the greater the temporal offset, the greater the disagreement between known turbidity (NTUM, NTUC) and estimated turbidity (NTUE). Uncertainty analysis consisted of plotting the residuals of model estimates against their respective temporal offsets.

\subsection{Image Selection and Processing}

Following model uncertainty analysis, we collected preprocessed surface reflectance data (http://landsat.usgs.gov/CDR_LSR.php) from Landsat TM and ETM+ where at least 10\% of the lake was visible. We selected images from May-October; the months that precede (May-June) or follow (September-October) peak growing season (July-August) of sockeye salmon within Lake Clark [31]. 
Further scene correction was required due to caveats associated with satellite observations at high latitudes, where snow cover is significant, and in areas with extensive cloud contamination. For each scene we used adjacent non-turbid water bodies for dark object subtraction. Kijik Lake $\left(60^{\circ} 18^{\prime} 05.02^{\prime \prime} \mathrm{N}\right.$ $\left.154^{\circ} 19^{\prime} 40.13^{\prime \prime} \mathrm{W}\right)$, a $4.3 \mathrm{~km}^{2}$, deep, clear water lake immediately adjacent to Lake Clark was used as the primary dark object (Figure 1). Secondarily, Portage Lake (60³0'17.48'N 15351'59.96"W), located 14 $\mathrm{km}$ north of the head of Lake Clark was used. If both Kijik and Portage lakes were obscured, a portion

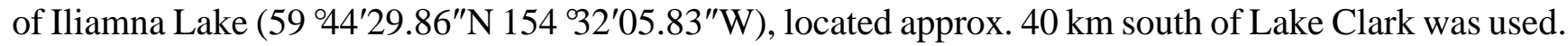
In all cases, the Band 3 digital number (DN) value for a swath of cells within the dark body was averaged and the value subtracted from Band 3 for the respective scene. The size of this swath varied from $0.5 \times 2.5 \mathrm{~km}$ to opportunistically sized swaths of cells $(\mathrm{n}=20+$ or $0.15 \times 0.15 \mathrm{~km})$.

Following scene correction, a standard Lake Clark polygon was used to exclude all data except reflectance data coming from the lake surface. This polygon was manually drawn around Lake Clark using a cloud free scene and a false-color composite band combination $(\mathrm{R}=$ Band $4, \mathrm{G}=\mathrm{Band} 3$, $\mathrm{B}=$ Band 2). All terrain was excluded and areas where the lake bottom was visible in the scene were clipped. Therefore all littoral zones including the upper sections of several large bays were clipped and excluded from analysis. Ultimately a $278.4 \mathrm{~km}^{2}$ portion of Lake Clark (roughly $90 \%$ of the reported area) was available for analysis. Clouds, cloud shadows, shadows from high peaks, lake ice, and additional lake bottom visible during low lake levels were manually clipped on a scene-by-scene basis. If more than $70 \%$ of the original polygon remained after clipping and all three basins were represented in the data, we considered the scene a whole-lake scene. Strips of missing data (data gaps) are present in all Landsat 7 scenes acquired after May 31, 2003 due to the failure of the Scan Line Corrector (SLC). We did not use any corrective measures to interpolate the missing data and considered cloud-free lake scenes to be whole-lake scenes even if SLC data gaps existed. Following pre-processing of suitable Landsat TM and ETM+ images, we estimated turbidity (NTUE) for all remaining pixels and output rasters with $30 \times 30 \mathrm{~m}$ cell size.

\subsection{Analysis of Estimated Water Clarity}

We analyzed spatial and temporal patterns in turbidity in Lake Clark between 1991 and 2014 by computing mean annual and mean monthly NTUE values for the whole-lake as well as the three basins and compared these data to time, air temperature and precipitation data sets. Assessing turbidity on a whole-lake scale, both within and among years, allowed us to track the dynamic nature of the Lake Clark turbidity plume. We examined turbidity at the basin level to assess whether individual basins respond differently to changes in water quality during the study period.

We compared the mean NTUE with available meteorological data in an effort to assess potential drivers in water clarity. Climate records came from Port Alsworth which is situated along the SE shore of Lake Clark (Figure 1) and is the location of the National Park Service Field Headquarters. The meteorological station (Port Alsworth Cooperative Observer Program station ID No. USC00507570) is the longest running meteorological record for the region. When exploring the significance of potential environmental drivers, we took a conservative approach and included only full-extent scenes. Mean NTUE values for the whole-lake and three basins were plotted against temperature and precipitation records.

We tested for trends and correlation using non-linear and simple linear regression. Depending on the test, we reported significance using Pearson's correlation coefficient $(r)$, the coefficient of determination 
$\left(r^{2}\right)$ and p-values. P-values greater than 0.05 suggested no significance to any of the measured trends or correlations.

\section{Results}

\section{1. $N T U_{M}, N T U_{C}, N T U_{E}$ and Landsat Image Stack}

There was strong correlation $\left(r^{2}=0.98\right)$ between SDT measurements and simultaneous measurements from a calibrated nephelometer (NTUM) (Figure 2). This relation allowed us to derive NTUC values for all SDT data collected during other sampling periods (Equation (1), Figure 2):

$$
N T U_{C}=9.4109(S D T)^{-1.243}
$$

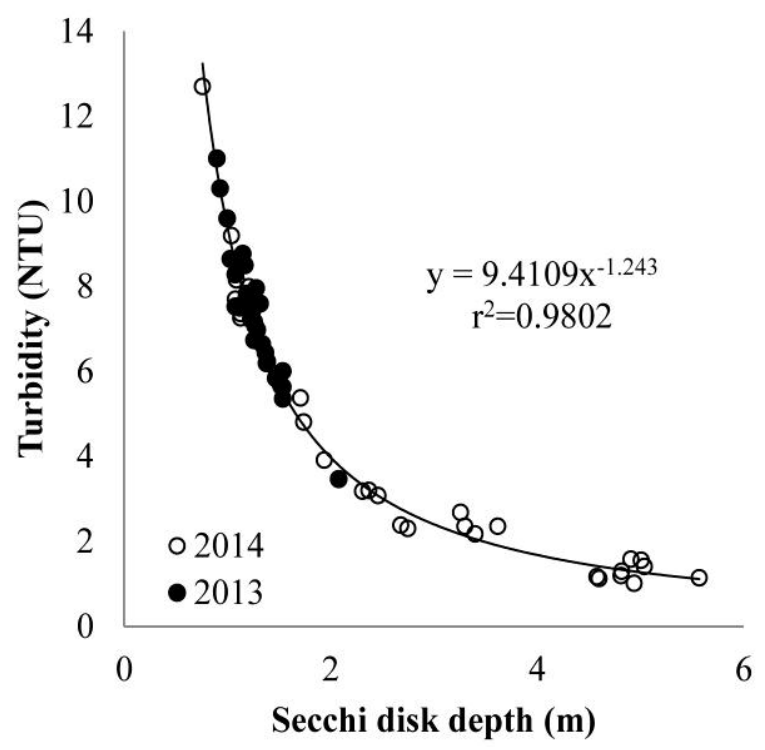

Figure 2. A strong correlation exists between Secchi disk transparency (SDT) measurements and simultaneous measurements from a calibrated nephelometer (NTUM). This relation is specific to Lake Clark and allows for historical SDT measurements to be converted into standard Nephelometric Turbidity Units (NTUC).

There was a significant relation $(p$-value $<0.05)$ between NTUC values and Landsat reflectance values for each of the four bands as well as all eight band combinations (Table 1). A linear relationship based on Band 3 was ultimately selected for its highest adjusted $r^{2}$ value $(0.55)$, smallest $p(<<0.01)$, and smallest residual standard error (2.15). Figure 3 demonstrates the agreement between the measured and estimated NTU values used in model calibration.

Model uncertainty analysis using NTUM and NTUC values acquired in August 2009, September 2010, August 2012, August 2013, and September 2013 revealed that the greater the temporal offset between water sampling date and scene acquisition date, the greater the mean residual error (Figure 4). This satisfied our expectation that an effective model will perform better the closer the scene acquisition is to the date of water sampling. While other studies have employed a mean reflectance value of an array of cells surrounding the in situ sample point [13] we found no improvement over the single cell approach. 


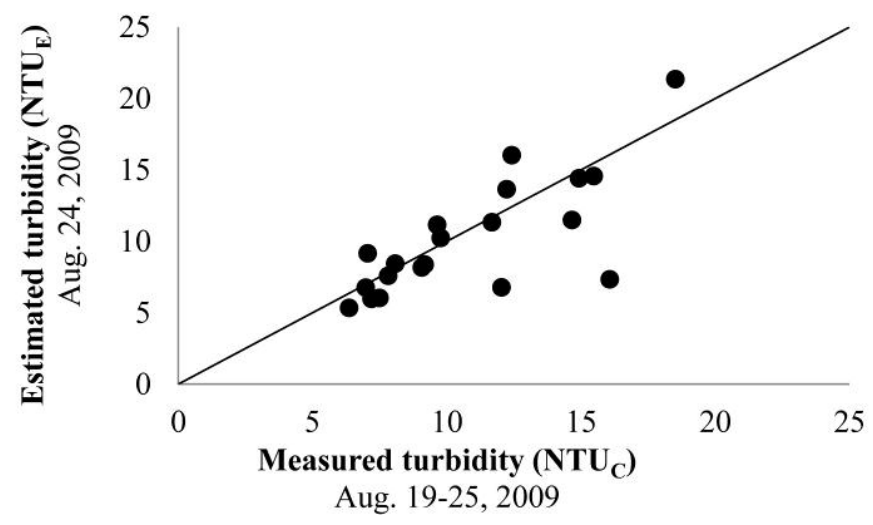

Figure 3. A strong correlation $\left(r^{2}=0.55\right)$ exists between turbidity measured in the field (NTUC) and NTU values estimated remotely.

Table 1. Relations between NTUC and Landsat bands or band combinations. Turbidity data acquired in August 2009. Table ordered from highest to lowest $R^{2}$.

\begin{tabular}{ccccc}
\hline & Function & $\boldsymbol{R}^{2}$ & $\boldsymbol{p}$ & RMSE \\
\hline $\mathrm{b} 3$ & $\mathrm{Y}=0.01826^{*} \mathrm{~b} 3+4.75422$ & 0.55 & $<<0.01$ & 2.42 \\
$\mathrm{~b} 3+\mathrm{b} 4$ & $\mathrm{Y}=0.014938(\mathrm{~b} 3)+0.021468(\mathrm{~b} 4)+8.1739$ & 0.54 & $<<0.01$ & 2.45 \\
$\mathrm{NDTI}$ & $\mathrm{Y}=30.048^{*}(\mathrm{NDTI})+25.129$ & 0.53 & $<<0.01$ & 2.46 \\
$\mathrm{~b} 3 / \mathrm{b} 2$ & $\mathrm{Y}=31.371(\mathrm{~b} 3 / \mathrm{b} 2)-0.4613$ & 0.52 & $<<0.01$ & 2.48 \\
$\mathrm{~b} 2+\mathrm{b} 3$ & $\mathrm{Y}=0.003(\mathrm{~b} 2)+0.014(\mathrm{~b} 3)+3.146$ & 0.52 & $<<0.01$ & 2.48 \\
$\mathrm{~b} 2$ & $\mathrm{Y}=0.01412 * \mathrm{~b} 2-1.696681$ & 0.52 & $<<0.01$ & 2.49 \\
$\mathrm{~b} 1+\mathrm{b} 2+\mathrm{b} 3+\mathrm{b} 4$ & $\mathrm{Y}=-0.01 * \mathrm{~b} 1+0.007 * \mathrm{~b} 2+0.014 * \mathrm{~b} 3+0.025 * \mathrm{~b} 4+8.68$ & 0.49 & 0.01 & 2.55 \\
$\mathrm{~b} 1 / \mathrm{b} 3$ & $\mathrm{Y}=-4.5668(\mathrm{~b} 1 / \mathrm{b} 3)+20.733$ & 0.46 & $<<0.01$ & 2.63 \\
$\mathrm{~b} 4 / \mathrm{b} 3$ & $\mathrm{Y}=10.255^{*}(\mathrm{~b} 4 / \mathrm{b} 3)+15.054$ & 0.46 & $<<0.01$ & 2.64 \\
$\mathrm{~b} 1$ & $\mathrm{Y}=0.01715 * \mathrm{~b} 1-0.42830$ & 0.44 & $<<0.01$ & 2.68 \\
$\mathrm{~b} 4 / \mathrm{b} 1$ & $\mathrm{Y}=31.452(\mathrm{~b} 4 / \mathrm{b} 1)+16.442$ & 0.40 & $<0.01$ & 2.77 \\
$\mathrm{~b} 4$ & $\mathrm{Y}=0.07608 * \mathrm{~b} 4+19.0382$ & 0.39 & $<0.01$ & 2.81 \\
\hline
\end{tabular}

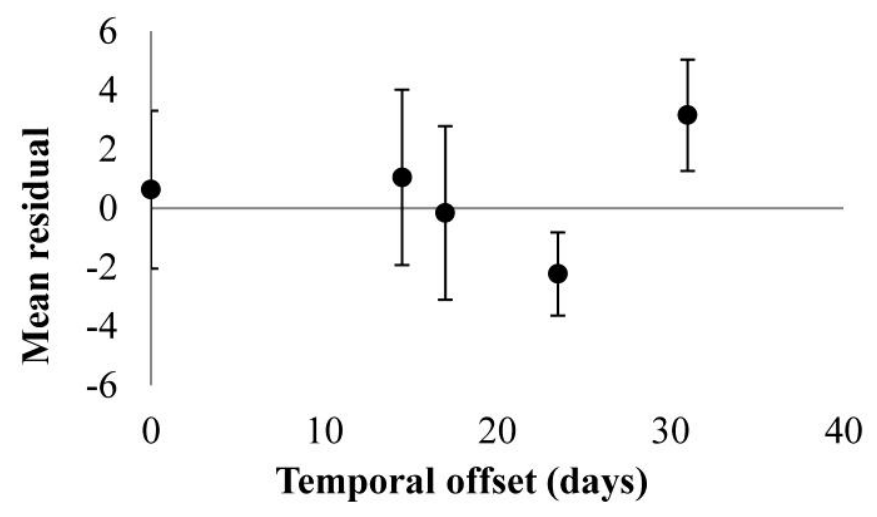

Figure 4. Model uncertainty analysis results. Our model was tested on four additional scenes where in situ NTUC values could be compared to model estimates. The data points show that the greater the temporal offset, the greater the uncertainty in the model estimates as indicated by the inflation of the mean residual. 
Our Landsat image stack consisted of 151 scenes (Landsat TM and ETM+) in which the whole lake $(n=53)$ or a portion $(n=98)$ of Lake Clark was visible during May-October. The first available scene was acquired on July 30, 1985 and the last scene was acquired on July 29, 2014. Nine years (1988-1990, 1992-1994, 1996-1998) had no scenes available and seven years (1992-1994, 1996-1998, and 2006) had no whole-lake, cloud-free imagery. On average, $78 \pm 12$ scenes contributed to turbidity estimates for each lake pixel. The degree of scene coverage varied across Lake Clark with the northeast section of the lake cloud-free more often than the southwest portion. Specifically, one location in the northern end of the lake was covered by a maximum of 106 scenes. A southwestern location of the lake only received data from 15 scenes.

\subsection{Trends in Turbidity at Different Spatial and Temporal Scales}

Identifying year-to-year trends is best accomplished by comparing whole-lake Landsat scenes where the entire lake is visible. Fifty $(\mathrm{n}=50)$ cloud-free, whole-lake scenes were acquired between 1999 and 2014, two $(n=2)$ scenes were acquired in 1995 and one $(n=1)$ in 1991. No scenes were available for 2006.

Water clarity fluctuated on an annual basis, showed short term (sub-decadal) trends, and little to no long-term trend between 1991 and 2014 (Figure 5). Annual scene count had little relation to annual mean NTUE value ( $\left.r=0.07, r^{2}=0.01, p=0.77, n=17\right)$ but was related to annual standard deviation $\left(r=0.47, r^{2}=0.23, p=0.05, n=17\right)$. Thus, the variation in annual mean NTUE was not a product of available scenes but a realistic representation of annual variation in lake water clarity.

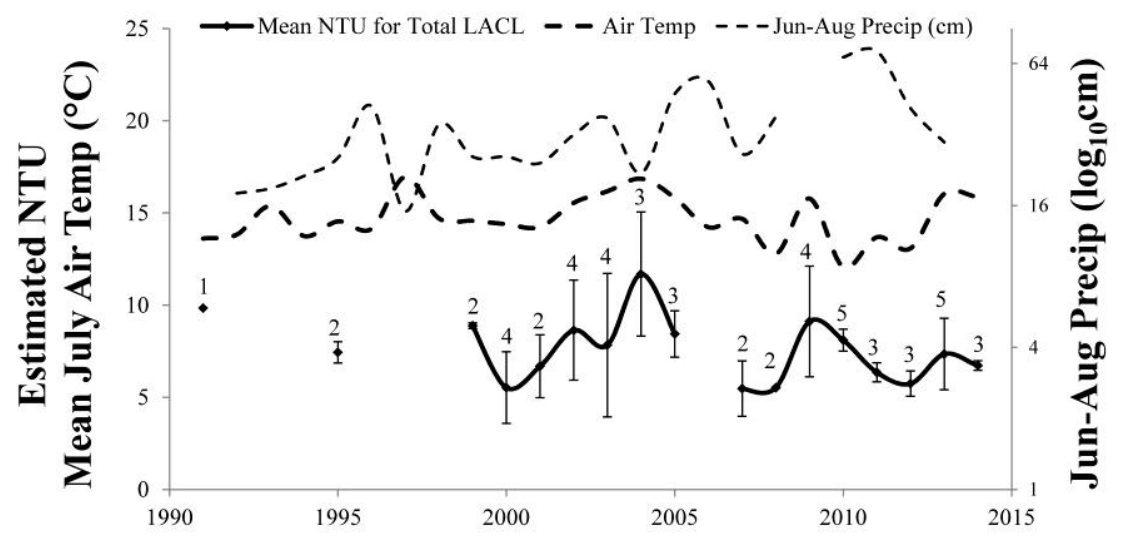

Figure 5. Trend in mean annual estimated turbidity $\left(\mathrm{NTU}_{\mathrm{E}}\right)$ for the entirety of Lake Clark, based on full-extent scenes $(n=53)$. Error bars represent standard deviations. Numbers represent sample sizes of contributing scenes for each year. Recorded mean July air temperature and mean June-August precipitation are reported as potential drivers of variation in turbidity.

We did not detect a positive trend in mean turbidity for the whole lake during the study period. The trend of mean NTUE for the whole of Lake Clark between 1991 and 2014 was slightly negative $(r=-0.35)$. However, this trend was not significant $\left(r^{2}=0.13, p=0.16, n=17\right)$. There was potential evidence for a stronger negative trend in water clarity over the last decade $(r=-0.51)$ however this too was not statistically significant $\left(r^{2}=0.26, p=0.13, n=10\right)$. 
Within the basins there was an insignificant and slightly negative trend over time for NTUE values for all months (Table 2) except May which had a significant positive trend between 2000 and 2014 $\left(r=0.82, r^{2}=0.68, p=0.02, n=7\right)$.

Table 2. Least squares regression statistics for whole-lake mean NTUE by month.

\begin{tabular}{cccccc}
\hline \multicolumn{7}{c}{ Regression Statistics } \\
\hline & Available Range & Pearson's $\boldsymbol{r}$ & $\boldsymbol{r}^{2}$ & $\boldsymbol{p}$ & $\boldsymbol{n}$ \\
\hline May & $2000-2014$ & 0.82 & 0.68 & 0.02 & 7 \\
Jun. & $2001-2013$ & -0.42 & 0.17 & 0.31 & 8 \\
Jul. & $2000-2014$ & -0.12 & 0.01 & 0.80 & 7 \\
Aug. & $1991-2012$ & -0.22 & 0.05 & 0.63 & 7 \\
Sept. & $1995-2013$ & -0.46 & 0.21 & 0.30 & 7 \\
Oct. & $1995-2011$ & -0.36 & 0.13 & 0.64 & 4 \\
\hline
\end{tabular}

When analyzed independently, all three Lake Clark basins exhibited similar fluctuations in NTUE values as that of Lake Clark as a whole (Figure 6). The interannual range of NTUE values was greatest for the upper basin and least for the lower basin. The upper and middle basins showed a slight but insignificant negative trend through time ( $r=-0.30$ and $-0.41, r^{2}=0.08$ and 0.17 respectively) while the lower basin showed no trend.

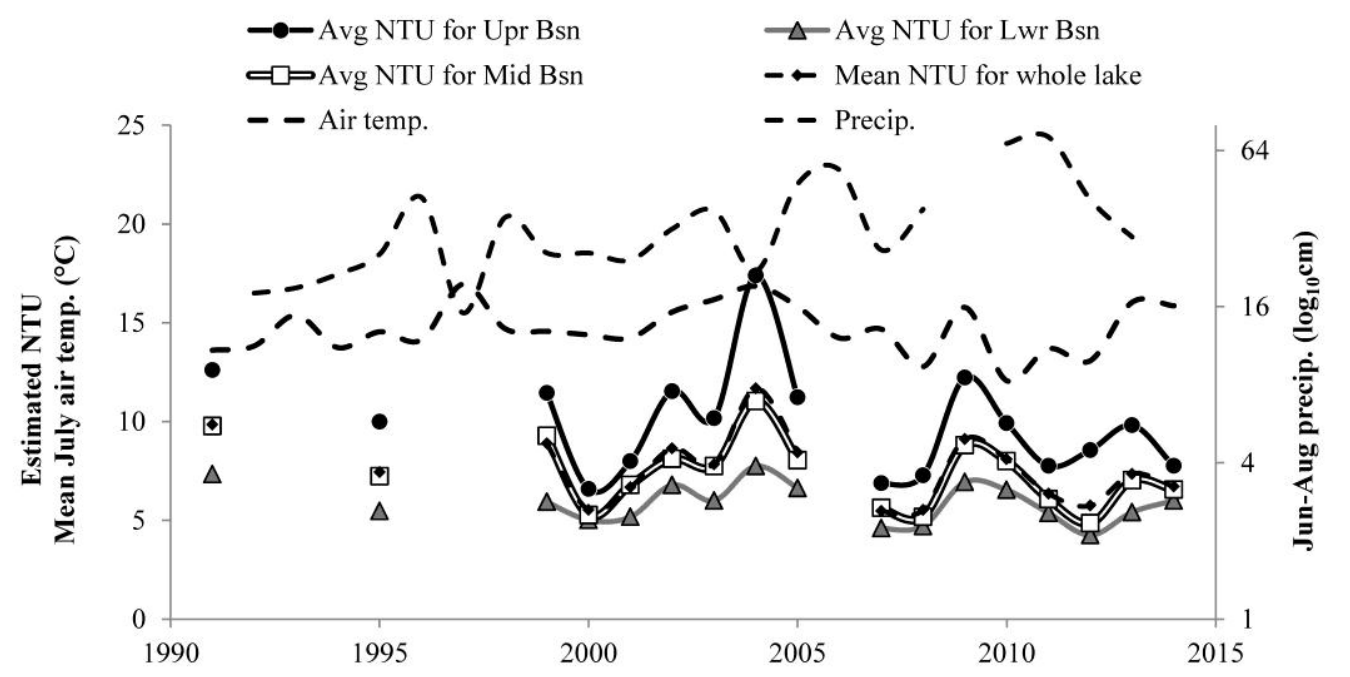

Figure 6. Average turbidity for the entire lake as well as each basin based on all whole-lake scenes $(\mathrm{n}=53)$.

\subsection{Additional Patterns Based on All Available Scenes.}

Partial lake scenes were available for earlier years (1985-1987) as well as the years in which whole-lake scenes were available. These $(n=98)$ partial lake scenes capture NTUE values for at least some portion of Lake Clark back to 1985 . When combined with the $(n=53)$ whole-lake scenes, not every year or month was represented, but we were able to use 151 scenes to identify general patterns of within-year variability. 
In May, Lake Clark was generally homogenous with relatively low turbidity values; whole-lake mean NTUE values ranged between 3.7 and 8.8. Lake ice was still visible on portions of the lake on May 10, 2000 (Figure 7a). May sediment plumes were detected in $25 \%$ of the seven whole-lake scenes acquired for 2004, 2009, 2013, and 2014.

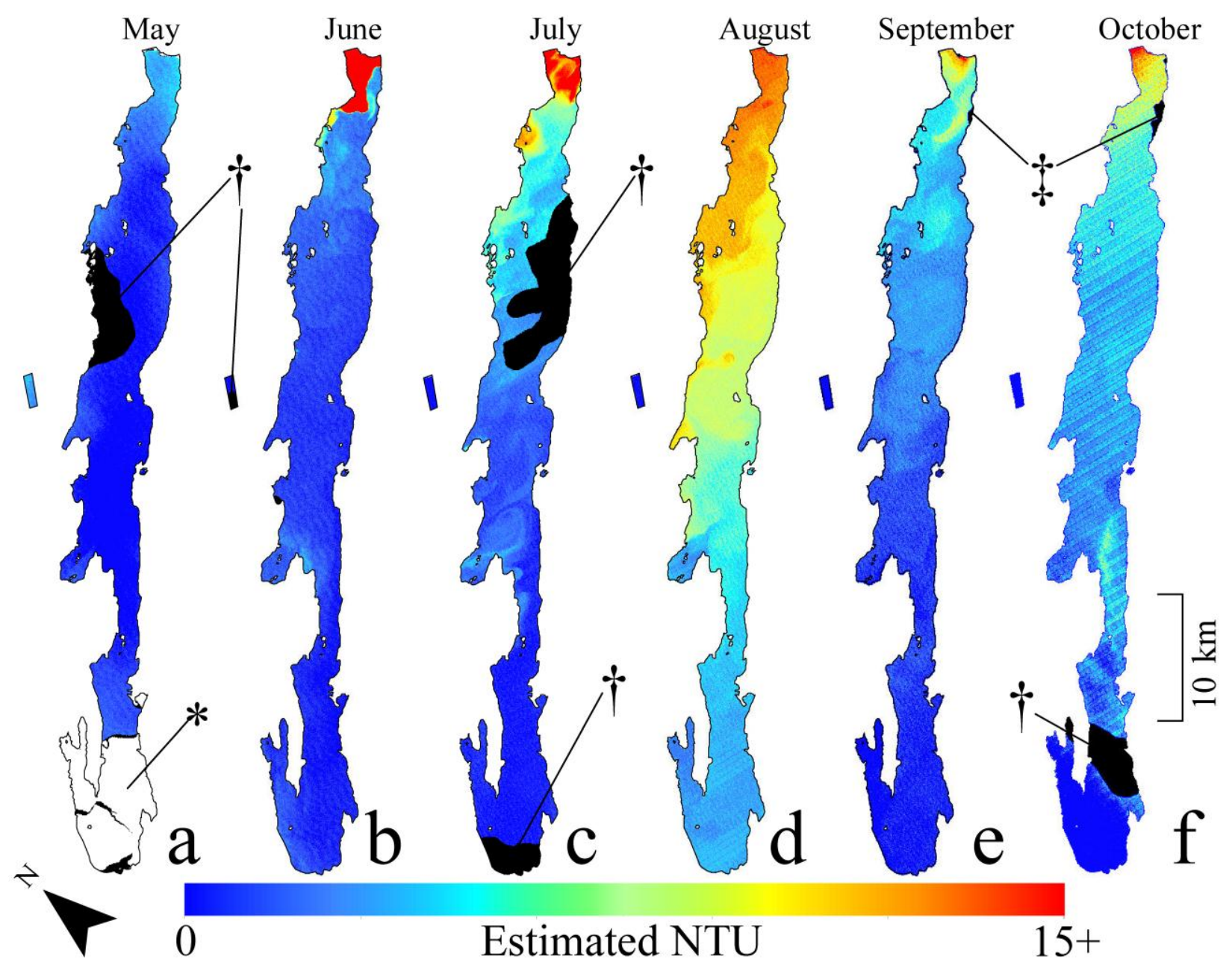

Figure 7. Characteristic spatial patterns of lake-wide turbidity estimated from Landsat images acquired during the study period. (a) May 10, 2000: Whole-lake mean NTUE $=2.45$. (b) June 17, 2002: Mean NTUE = 6.40. (c): July 20, 2011: Gyres are visible in the middle basin. Mean $\mathrm{NTU}_{\mathrm{E}}=6.86$. (d) August 30, 1991: Mean $\mathrm{NTU}_{\mathrm{E}}=9.83$. (e) September 19, 2010: Mean NTUE= 7.34. (f) October 5, 2010: Shadows cast by mountains are visible in (e) and (f) and are common in late season scenes. All Figures: A subset of Kijik Lake, used in dark object subtraction, is consistently sediment free. $*=$ Lake ice, $\dagger=$ Cloud shadow, $\ddagger=$ Mountain shadow.

In June, visually prominent sediment plumes were detected in 30 out of 36 scenes. While most plumes had NTUE values between 10 and 20, some NTUE values were as high as 30 (Figure 7b). For the month of June, $100 \%$ of whole-lake scenes $(n=12)$ exhibited prominent sediment plumes. Sediment plumes could be restricted to the upper basin or were beginning to disperse in the lake. The earlier in the month the scene was 
acquired, the more likely the plume was to be confined to the upper basin (Figure 7). Turbidity values were also higher for turbid zones of the lake indicating concentrated sediment had not dispersed.

July scenes were characterized by a more dispersed distribution of turbid water, presumably from currents and wind induced mixing. As the sediment plume dispersed, turbidity values increased across the entire lake, while maximum NTUE values decreased. For example, on 29 June 2009, maximum NTUE within the plume was $26 \mathrm{NTUE}$, with the remainder of Lake Clark exhibiting a mean NTUE of $5.37 \pm$ 0.91. By 7 July 2009, maximum turbidity decreased to 16 NTUE and a lake-wide mean of $5.96 \pm 1.09$ NTUE. For the $\mathrm{n}=21$ July scenes, seven scenes exhibited gyres, rotational circulation patterns often found in lakes and oceans and often caused by wind. Counter-clockwise (ccw) gyres occurred in four scenes $(1987,2000,2005,2007)$, clockwise (cw) gyres occurred in two scenes (2003, 2013) and one scene in 2011 exhibited both (Figure 7).

In August scenes, the turbidity gradients generally persisted with the upper basin being regularly more turbid than the middle and lower basins. High contrast plumes were visible in a number of scenes, while others showed little structure due to the largely dispersed plume. Lake-wide sediment dispersal by August agrees with Chamberlain et al. [24]. Multiple scenes also depicted gyres. For example, a ccw gyre is evident in the image from 30 August 1991 (Figure 7d).

September scenes were characterized by the progression of the sediment plume to the middle and lower basins of the lake and prominent gyres were common. On 15 September 2000, five ccw gyres were present roughly in the middle of the lake and a prominent sediment plume extended to the lower reaches of the lake. Over the course of two days in 2010 (19-20 September) four or more gyres, located between the upper and middle basins, progressed down-lake. These gyres are faintly visible in Figure 7e. The majority of gyres were ccw but small cw gyres were also present. By 27 September 2010, these sediment plumes had dissipated somewhat but two or more ccw gyres remained.

The turbidity gradient became more diffuse through October with lake-wide turbidity becoming more homogenous (Figure 7f). Occasionally, prominent sediment plumes were detected in October. Pronounced plumes were evident in the upper basin in images from 5 October 1995 and 12 October 2003. Full lake scenes are rare for October due to increased cloudiness, which makes lake-wide assessments difficult for this month.

\subsection{Lake Clark Turbidity and Environmental Conditions}

There was positive correlation between water clarity and air temperature within the whole lake. Correlation with mean July temperature was non-significant with changes in mean NTUE $(r=0.45$, $\left.r^{2}=0.20, p=0.06\right)$. Mean June-August air temperature was more significantly correlated $(r=0.67$, $\left.r^{2}=0.44, p \leq 0.01\right)$. There was a slightly negative correlation $(r=-0.14)$ between turbidity and precipitation however this correlation was insignificant $\left(r^{2}=0.02, p=0.63\right)$ (Table 3). Correlation was also present within lake basins. The highest degree of correlation came from mean June-August air temperature and mean annual turbidity values in the upper basin $(r=0.69)$. This relation becomes weaker in the middle and lower basins ( $r=0.65$ and 0.60 , respectively).

While statistically weak, water clarity appears to be correlated with the environmental parameters analyzed. Manual interpretation reveals periods of high turbidity to be somewhat aligned with periods of high air temperature and low precipitation values recorded at Port Alsworth (Figures 5 and 6). A 
prominent spike in turbidity for 2009 aligned with warm July air temperatures and reduced June-August precipitation totals. A three year period of increased turbidity centered around 2004 was preceded by multiple years of warmer than normal summers. In March 2009, the eruption of Mt. Redoubt deposited ash throughout southwest Alaska including Lake Clark. The 2009 spike in turbidity likely represents this event in part. The subsequent increase in water clarity following the 2009 spike may represent slow recovery from the influx of volcanic ash following that event [26].

Table 3. Pearson correlation matrix between Lake Clark weather data for 1991-2014 and mean NTUE for different regions of Lake Clark when available. Only full extent scenes included ( $\mathrm{n}=53$ ). No Landsat data available for 1992-1994, 1996-1998, and 2006.

\begin{tabular}{cccc}
\hline & $\begin{array}{c}\text { Mean July Air Temp. } \\
\left({ }^{\circ} \mathbf{C}\right)\end{array}$ & $\begin{array}{c}\text { Mean June-August Air } \\
\text { Temp. }\left({ }^{\circ} \mathbf{C}\right)\end{array}$ & $\begin{array}{c}\text { Total June-August Precip. } \\
(\mathbf{c m})\end{array}$ \\
\hline Whole-lake mean NTU & 0.45 & 0.67 & -0.14 \\
Upper basin mean NTUE & 0.47 & 0.69 & -0.2 \\
Middle basin mean NTUE & 0.43 & 0.65 & -0.17 \\
Lower basin mean NTU $_{\mathbf{E}}$ & 0.43 & 0.6 & 0.04 \\
\hline
\end{tabular}

\section{Discussion}

\subsection{Detection and Mapping of Glacial Sediment Plumes}

Our study successfully reconstructed the spatial and temporal distribution of turbid water in Lake Clark, Alaska using Landsat TM and ETM+ imagery collected between 1985 and 2014. Similar retrogressive analyses have been completed via Landsat MSS and TM sensors focused on 500 lakes across a $7700 \mathrm{~km}^{2}$ metropolitan area in Minnesota, USA [12] and in Waikato region New Zealand using the ETM+ sensor [13]. Our compilation of suitable, whole-lake Landsat images extended whole-lake turbidity estimates for Lake Clark back 13 years compared to in situ measurement data, which only extends back five years and is based on sampling of 15 to 30 points at a time during a particularly restrictive sampling period. When we utilized all available scenes, we were able to estimate turbidity for all or part of Lake Clark as far back as 29 years. We were also able to document the presence/absence and extent of the sediment plume within Lake Clark in greater detail than had been previously accomplished. Comparing Landsat images of the sediment plume to in situ measurements, we were also able to successfully convert surface reflectance into estimated NTU values and, therefore, estimate the severity of the plume at various spatial and temporal scales. This approach has been documented elsewhere, including studies at northern latitudes such as turbidity mapping in Vitus Lake, Alaska via ETM+ data [20] and sediment plume monitoring in Kangerlussuaq Fjord, Greenland [32] via the MODIS sensor on NASA's Terra satellite.

Band 3 of the TM and ETM+ sensors proved to be most useful in our study but is not an exclusive resource for mapping water clarity in glacier-influenced water bodies in high latitudes. Jenkins [20] found a combination of Bands 3 and 4 to be most effective at detecting glacier runoff sediment plumes within a glacier margin lake. Using coarser (500 m) MODIS reflectance data, Chu et al. [32] found peak reflectance for glacier derived sediment plumes at 0.65 and $0.82 \mu \mathrm{m}$, which aligns closely with Landsat ETM+ Band $3(0.63-0.69 \mu \mathrm{m})$ and Band $4(0.76-0.90 \mu \mathrm{m})$. 


\subsection{Interannual Trends in Lake Clark Water Clarity}

Regardless of the absence in long-term trends, there is substantial evidence for pronounced interannual variability in turbidity within Lake Clark (Figure 5) and in all three lake basins (Figure 6). These variations appear to be at least slightly correlated with mean June-August air temperature and total June-August precipitation. There is reason to believe this correlation to be causal. Warm air temperature promotes glacier and snow melt at upper elevations which increases flow and sediment transport in rivers like the Tlikakila. Chu et al. [32] concluded the size and magnitude of the Kangerlussuaq Fjord sediment plume was directly related to the amount of seasonal melt experienced by the contributing glacier. Jenkins [20] was also able to draw direct links between glacier melt events and turbidity patterns. Large precipitation events have been shown to positively correlate with glacier flow dynamics [33] so cool rainy summers or extreme precipitation events could also influence glacier flow rate and sediment production.

Strong patterns supporting this mechanism are currently absent in our study. Remote sensing was used to reconstruct glacier positions in 1957, 1978, and 2004 [25]. Glacier volume was estimated for 1957 and 2001 and mass balance estimates were conducted in 2001. While these investigations found glacier extent and volume to have decreased over the last half century, these observations are temporally limiting, with only two observations occurring during our study period. Thus, we cannot directly compare glacier melt and Lake Clark water clarity. Focused study on glacier activity or seasonal sediment loads within the Tlikakila River could better inform this component. The potential observation of increased turbidity in Lake Clark following the eruption of Mt. Redoubt is an interesting point of future study and could be confirmed by hindcasting turbidity in other regional lakes.

The month of May showed a significant positive trend in turbidity between 2000 and 2014. This trend is based on seven scenes $(n=7)$ and therefore could be an artifact of the images available for those dates. It is also possible that this could represent an advance in the timing of sediment deposition from the Tlikakila River during this period. We are not aware of stream flow or suspended sediment measurements needed to verify this observation. Such measurements were collected during 1999 and 2001 [27] and could be compared to present rates should monitoring resume.

\subsection{Intra-Annual Trends in Lake Clark Water Clarity}

Remotely sensed images from this study depict that the Lake Clark sediment plume was very dynamic on an intra-annual scale. This is important when considering field based monitoring. August has been identified in the past as the general period when Lake Clark experiences lake-wide increases in NTU values. Our data appear to support this. However, since we have large temporal data gaps it is difficult to pinpoint exactly when peak sediment flow occurs based on our data.

Assessments of whole-lake suspended sediment patterns via Landsat showed that turbidity structure can change significantly over the course of a week. In September 2010, a sediment plume extended $23 \mathrm{~km}$ from the upper basin to the middle basin in seven days. In this case, the rate of spread of suspended sediment is likely dictated by wind-driven water currents within the lake.

Presumably there is a constant flow of water from the upper basin to the lower basin that would also transport suspended sediment. Inflow rates and lake volume have been measured in detail but only for 
short periods of time. Hourly measurements and a detailed water budget analysis for Lake Clark were completed between 1999 and 2001. If more scenes were available during this time, the relationship between retention time and sediment dispersion could be better explored.

The detection of gyres also suggests that wind currents likely play a large role in mixing lake water and suspended sediment. Gyres form as a function of wind direction and lake bed structure [34]. Therefore, all things being equal, a prevailing wind will produce a prevailing gyre. If wind data is available or collected and paired with ongoing temperature surveys of the water column, this mechanism could be further substantiated and prove more effective than temperature data collection alone.

While we detected no long-term trend in Lake Clark's water clarity, changes in the spatial and temporal distribution of the glacial sediment plume would affect productivity and the distribution of fish species and should therefore remain the focus of future studies. Primary productivity and feeding success of fish that rely on visual cues can be significantly affected by increasing turbidity [5]. It has been suggested that turbidity gradients in Lake Clark may result in segregation between species that feed in the pelagic zone. Schlenger [35] found that sockeye salmon were distributed throughout the lake while least cisco (Coregonus sardinella) were found primarily in the turbid north end of the lake. These distributional differences were stable throughout the summer season and across years. Feeding morphology of least cisco suggested adaptation to use similar food resources as juvenile sockeye salmon throughout their lives. Schlenger [35] suggested that the differential distribution reflected species specific risk-sensitive foraging behavior and that sockeye salmon were more willing to risk predation in the clear south end of the lake to obtain food than least cisco. If the spatial extent of the turbidity plume increased, it is not known if this could result in less lacustrine habitat for sockeye salmon or simply more overlap between the two species, resulting in greater competition for the same food resources. If this caused the size-at-maturity of sockeye to decrease, it could mean higher mortality when they initially reach the ocean.

Changes in water clarity have also been documented to influence spawning activity within sockeye salmon. Ramstad et al. [36] found that increased turbidity correlated with longer snouts in breeding adults and females having pink body coloration as opposed to red. These attributes are attributed to reduced visibility. Sexual signaling via red body color is less effective in turbid waters and therefore an unnecessary use of valuable carotenoids [36]. Pink coloration could make spawning fish less visible to predators [36]. In turbid waters, the chance of physical encounters increases and the need for longer snouts as weapons and appears to be an evolutionary response [36]. Long-term and significant changes (positive or negative) in water clarity within Lake Clark would therefore provide significant selective pressure on sockeye salmon phenotypes.

\subsection{Challenges and Future Strategies}

This study demonstrates that water clarity measurements via remote sensing can be challenging yet cost effective and useful in Alaska. Cloud cover is the single greatest limiting factor frequently encountered in Alaska that hinders both retrospective and ongoing water monitoring efforts that involve remotely sensed data. For our study period, there were 192 and 446 scenes available from Landsat 4/5 and 7 , respectively. In only $24 \%(\mathrm{n}=151)$ of available scenes was Lake Clark not completely cloud covered and in only $8 \%(n=53)$ was Lake Clark cloud free. Cloud and topographical shadows regularly 
cast over portions of the lake further detracted from these full-extent scenes especially outside of the growing season when sun angles are low throughout the day. By comparison, Kloiber et al. [12] in a study of Minnesota lakes achieved a 30\% chance of any image being cloud free. Within Alaska, Lake Clark is not exceptionally cloudy (http://www.wrcc.dri.edu/htmlfiles/westcomp.ovc.html) so these ratios should be considered in the future when exploring satellite-based retrospective investigations for other northern high latitude lake systems.

Another limitation to this approach may come from the TM and ETM+ sensors inability to image deep bathymetry. The depth of penetration of incoming radiation is inhibited by turbidity and limited to the upper $30 \mathrm{~m}$ even in clear water. Therefore our results pertain to the surface and near surface conditions of Lake Clark which may or may not represent the overall condition of the entire water column. Our use of Band 3 is particularly limited as red light (Band 3) is readily attenuated within water.

Further improvement of this approach will depend on availability of physically measured data and simultaneously acquired imagery. The relationships used in this study, while sufficient, could be improved with the addition of turbidity measurements acquired in tandem with Landsat overflights on cloud free days [16]. A stationary or roving automated water sampling device such as the Automated Lagrangian Water Quality Assessment System has proven to be highly useful at guaranteeing in situ samples are collected regularly and in coordination with overflights [20]. Over time, continued sampling could greatly improve the relation between in situ measurements and observed reflectance in Lake Clark as well as other glacially influenced lakes.

The relationships developed for Lake Clark could be applied to adjacent lakes that may otherwise be cost prohibitive to monitor $[12,16]$. Kontrashibuna Lake $\left(60^{\circ} 11^{\prime} 17.97^{\prime \prime} \mathrm{N} 154^{\circ} 03^{\prime} 17.11^{\prime \prime} \mathrm{W}\right)$, Twin Lakes $\left(60^{\circ} 38^{\prime} 03.46^{\prime \prime} \mathrm{N} 153^{\circ} 55^{\prime} 10.89^{\prime \prime} \mathrm{W}\right)$, Turquoise Lake $\left(60^{\circ} 47^{\prime} 21.71^{\prime \prime} \mathrm{N} 153^{\circ} 56^{\prime} 38.04^{\prime \prime} \mathrm{W}\right)$, and Telequana Lake $\left(60^{\circ} 57^{\prime} 18.56^{\prime \prime} \mathrm{N} 153^{\circ} 52^{\prime} 45.25^{\prime \prime} \mathrm{W}\right)$ are all fed by rivers that originate in the same glacier-clad Neacola Mountains that drain into Lake Clark. Subsequently their suspended sediment may be spectrally similar due to shared origins. While direct applications should be made with caution, initial assessments of these lakes could begin using the methods and results reported here. The continuation of the Landsat mission and the spectral overlap between Band 3 of the TM and ETM+ with the Landsat 8 OLI sensor ensures that this data set and studies like this one will be possible in the future.

\section{Conclusions}

In this study, we incorporated a two-step process in which we linked $\mathrm{NTU}_{M}$ with $\mathrm{NTU}_{C}$ and then

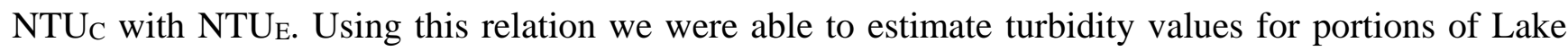
Clark for 151 scenes acquired between May and October during the years 1985-2014. Fifty three of these scenes were nearly cloud free and offered exceptional insight into historical conditions of turbidity within Lake Clark. Analysis of available data showed no significant long-term trend in mean annual NTUE values for Lake Clark but there was a potential correlation with July air temperature and a volcanic eruption event. Observations for May exhibited a significant positive trend in turbidity between 2000 and 2014 and could represent an advance in the timing of initial sediment input to the lake. Lastly, the presence of gyres in many mid- and late-season scenes suggests wind may influence the spatial distribution of turbidity in Lake Clark. The continuation of the Landsat mission and on-the-ground field campaigns means this study can continue and be improved as more data becomes available. 


\section{Acknowledgments}

This project was funded by the National Park Service and the U.S. Geological Survey-Alaska Science Center, Land Remote Sensing Program, and Land Change Science Program. We thank the staff of Lake Clark National Park and Preserve for logistic support and Jen Wiley, Jeff Nelson, Evan Booher, and Nicole Abeln for help in the field. Use of trade, product, or firm names is for descriptive purposes only and does not imply endorsement by the U.S. Government.

\section{Author Contributions}

$\mathrm{CAB}$ compiled and analyzed remotely sensed data, developed statistical relations, and wrote the manuscript. BMJ and CEZ conceived the study design, contributed data, and assisted in manuscript writing. KB and DY contributed data, assisted in data interpretation and manuscript writing.

\section{Conflicts of Interest}

The authors declare no conflict of interest.

\section{References}

1. Kirk, J.T.O. Light and Photosynthesis in Aquatic Ecosystems; Cambridge University Press: Cambridge, UK, 1994.

2. Effler, S.W. Secchi disc transparency and turbidity. J. Environ. Eng. 1988, 114, 1436-1447.

3. Donohue, I.; Garcia Molinos, J. Impacts of increased sediment loads on the ecology of lakes. Biol. Rev. 2009, 84, 517-531.

4. Engström-Öst, J.; Candolin, U. Human-induced water turbidity alters selection on sexual displays in sticklebacks. Behav. Ecol. 2007, 18, 393-398.

5. Lloyd, D.S. Effects of turbidity in fresh waters of Alaska. North Am. J. Fish. Manag. 1987, 7, 18-33.

6. Dolan, R.; Howard, A.; Gallenson, A. Man's impact on the Colorado River in the Grand Canyon: The Grand Canyon is being affected both by the vastly changed Colorado River and by the increased presence of man. Am. Sci. 1974, 62, 392-401.

7. Judy, R.D., Jr.; Seeley, P.N.; Murray, T.M.; Svirsky, S.C.; Whitworth, M.R.; Ischinger, L.S. 1982 National Fisheries Survey Volume 1 Technical Report: Initial Findings; U.S. Fish and Wildlife Service: Washington, DC, USA, 1984.

8. Kirk, J.T.O. Effects of suspensoids (turbidity) on penetration of solar radiation in aquatic ecosystems. Hydrobiologia 1985, 125, 195-208.

9. Henley, W.F.; Patterson, M.A.; Neves, R.J.; Lemly, A.D. Effects of Sedimentation and Turbidity on Lotic Food Webs: A Concise Review for Natural Resource Managers. Rev. Fish. Sci. 2000, 8 , 125-139.

10. Davies-Colley, R.J.; Smith, D.G. Turbidity, suspended sediment, and water clarity: A review. J. Am. Water Resour. Assoc. 2001, 37, 1085-1101.

11. Boulton, A. Limnological Analyses, 2nd ed.; Wetzel, R.G., Likens, G.E., Eds.; Springer-Verlag: New York, NY, USA, 1991; Vol. 7. 
12. Kloiber, S.M.; Brezonik, P.L.; Bauer, M.E. Application of Landsat imagery to regional-scale assessments of lake clarity. Water Res. 2002, 36, 4330-4340.

13. Hicks, B.J.; Stichbury, G.A.; Brabyn, L.K.; Allan, M.G.; Ashraf, S. Hindcasting water clarity from Landsat satellite images of unmonitored shallow lakes in the Waikato region, New Zealand. Environ. Monit. Assess. 2013, 185, 7245-7261.

14. Allan, M.G.; Hamilton, D.P.; Hicks, B.J.; Brabyn, L. Landsat remote sensing of chlorophyll a concentrations in central North Island lakes of New Zealand. Int. J. Remote Sens. 2011, 32, 2037-2055.

15. Hadjimitsis, D.G.; Clayton, C.R.I.; Hope, V.S. An assessment of the effectiveness of atmospheric correction algorithms through the remote sensing of some reservoirs. Int. J. Remote Sens. 2004, 25, 3651-3674.

16. Pulliainen, J.; Kallio, K.; Eloheimo, K.; Koponen, S.; Servomaa, H.; Hannonen, T.; Tauriainen, S.; Hallikainen, M. A semi-operative approach to lake water quality retrieval from remote sensing data. Sci. Total Environ. 2001, 268, 79-93.

17. Harrington, J.A., Jr.; Schiebe, F.R.; Nix, J.F. Remote sensing of Lake Chicot, Arkansas: Monitoring suspended sediments, turbidity, and Secchi depth with Landsat MSS data. Remote Sens. Environ. 1992, 39, 15-27.

18. Aranuvachapun, S.; LeBlond, P.H. Turbidity of coastal water determined from Landsat. Remote Sens. Environ. 1981, 11, 113-132.

19. Stow, D.A.; Hope, A.; McGuire, D.; Verbyla, D.; Gamon, J.; Huemmrich, F.; Houston, S.; Racine, C.; Sturm, M.; Tape, K.; et al. Remote sensing of vegetation and land-cover change in Arctic Tundra Ecosystems. Remote Sens. Environ. 2004, 89, 281-308.

20. Jenkins, L.K. Satellite-derived turbidity monitoring in the ice marginal lakes at Bering Glacier. Geol. Soc. Am. Spec. Pap. 2010, 462, 351-360.

21. Weeks, D.P. Lake Clark National Park and Preserve, Alaska Water Resources Scoping Report; Technical Report NPS/NRWRD/NRTR-2001/292; United States Department of the Interior, National Park Service: Fort Collins, CO; Washington, DC, USA, 2003.

22. Brabets, T.P. Water Quality of the Tlikakila River and Five Major Tributaries to Lake Clark, Lake Clark National Park and Preserve, Alaska, 1999-2001; Water-Resources Investigations Report 024127; U.S. Department of the Interior, U.S. Geological Survey: Anchorage, AK, USA, 2002.

23. Wilkens, A.X. The Limnology of Lake Clark. Master's Thesis, University of Alaska, Fairbanks, AK, USA, 2002.

24. Chamberlain, D.M. Physical, and Biological Characteristics, and Nutrients Limiting Primary Productivity, Lake Clark, Alaska; Michigan Technological University: Houghton, MI, USA, 1989.

25. Brabets, T.P.; March, R.P.; Trabant, D.C. Glacial History and Runoff Components of the Tlikakila River Basin, Lake Clark National Park and Preserve, Alaska; U.S. Geological Survey Scientific Investigation Report 2004-5057; U.S. Department of the Interior, U.S. Geological Survey: Anchorage, AK, USA, 2004.

26. Moore, C.; Shearer, J. Water Quality and Surface Hydrology of Freshwater Flow Systems in Southwest Alaska: 2010 Annual Summary Report; National Park Service (NPS): Washington, DC, USA, 2011. 
27. Shearer, J.; Moore, C.; Bartz, K.; Booher, E.C.J.; Nelson, J. Monitoring Freshwater Systems in the Southwest Alaska Network: Standard Operating Procedures; Natural Resource Report NPS/SWAN/NRR - 2015/925.1; The National Park Service, Natural Resource Stewardship and Science: Fort Collins, CO, USA, 2015.

28. Zhao, D.; Cai, Y.; Jiang, H.; Xu, D.; Zhang, W.; An, S. Estimation of water clarity in Taihu Lake and surrounding rivers using Landsat imagery. Adv. Water Resour. 2011, 34, 165-173.

29. Wang, J.-J.; Lu, X.X.; Liew, S.C.; Zhou, Y. Retrieval of suspended sediment concentrations in large turbid rivers using Landsat ETM+: an example from the Yangtze River, China. Earth Surf. Process. Landf. 2009, 34, 1082-1092.

30. Ritchie, J.C.; Cooper, C.M.; Schiebe, F.R. The relationship of MSS and TM digital data with suspended sediments, chlorophyll, and temperature in Moon Lake, Mississippi. Remote Sens. Environ. 1990, 33, 137-148.

31. Rich, H.B.; Quinn, T.P.; Scheuerell, M.D.; Schindler, D.E. Climate and intraspecific competition control the growth and life history of juvenile sockeye salmon (Oncorhynchus nerka) in Iliamna Lake, Alaska. Can. J. Fish. Aquat. Sci. 2009, 66, 238-246.

32. Chu, V.W.; Smith, L.C.; Rennermalm, A.K.; Forster, R.R.; Box, J.E.; Reehy, N. Sediment plume response to surface melting and supraglacial lake drainages on the Greenland ice sheet. J. Glaciol. 2009, 55, 1072-1082.

33. O’Neel, S.; Echelmeyer, K.A.; Motyka, R.J. Short-term flow dynamics of a retreating tidewater glacier: LeConte Glacier, Alaska, USA. J. Glaciol. 2001, 47, 567-578.

34. Zhan, S.; Beck, R.A.; Hinkel, K.M.; Liu, H.; Jones, B.M. Spatio-temporal analysis of gyres in oriented lakes on the Arctic Coastal Plain of northern Alaska based on remotely sensed images. Remote Sens. 2014, 6, 9170-9193.

35. Schlenger, P.T. Distribution and Potential for Competition Between Juvenile Sockeye Salmon (Oncorhynchus Nerka) and Least Cisco (Coregonus Sardinella) in Lake Clark, Alaska; University of Washington: Washington, DC, USA, 1996.

36. Ramstad, K.M.; Woody, C.A.; Allendorf, F.W. Recent local adaptation of sockeye salmon to glacial spawning habitats. Evol. Ecol. 2009, 24, 391-411.

(C) 2015 by the authors; licensee MDPI, Basel, Switzerland. This article is an open access article distributed under the terms and conditions of the Creative Commons Attribution license (http://creativecommons.org/licenses/by/4.0/). 